PACS: 78

\title{
ANGULAR DEPENDENCE OF IONOLUMINESCENCE FOR SILICA CASE
}

\author{
DSergiy Kononenko, (D) Illia Mysiura, (D)Vitaliy Zhurenko*, \\ Oleg Shyshkin, DOganes Kalantaryan \\ V.N. Karazin Kharkiv National University \\ 4 Svobody Sq., Kharkov, 61022, Ukraine \\ *Corresponding Author:v.zhurenko@gmail.com \\ Received October 19, 2019; revised November 2, 2020; accepted November 6, 2020
}

\begin{abstract}
The paper deals with angular dependence of ionoluminescence from transparent glossy silica samples. We measured silica ionoluminescence spectra at wavelength range of 400-700 nm for different projectiles $\left(\mathrm{H}_{1}^{+}, \mathrm{H}_{2}^{+}, \mathrm{He}^{+} 210\right.$ and $\left.420 \mathrm{keV}\right)$ and registered two most common intensive emission peaks (blue with a maximum at $456 \mathrm{~nm}$ and red one at $645 \mathrm{~nm}$ ). To study luminescent angular dependence, the behavior of the blue peak maximum as a function of observation angle in the range of $0-70^{\circ}$ was examined, namely, the indicatrix at the wavelength of $456 \mathrm{~nm}$ was found. The intensity corresponding to ionoluminescent indicatrices were found to be higher with respect to values from Lambertian angular distribution reaching approximately $20 \%$ at large observation angles. We also calculated angular distribution of light above the sample surface taking into account refraction and reflection at the solid-ambient interface. The results obtained were in a good agreement with silica ionoluminescence experimental data for the average indicatrix curve. The latter indicates that the model assumption (luminescent light generated by fast ions within silica is unpolarized and isotropic) is correct. It was demonstrated that geometry of the experiment is very important, i.e., considering the light collected by the measuring system in a certain solid angle, one has to take into account that mutual arrangement of the sample and detector can distort angular distribution. The refraction at the border between a sample and vacuum (or air) strongly influences the luminescent light angular distribution.
\end{abstract}

KEY WORDS: $\mathrm{SiO}_{2}$; spectroscopy; refraction; reflection, ions, radioluminescence, spectrum, indicatrix

Luminescent methods have been used for diagnostic purposes in various fields of science and technology recently. Their main advantage is high sensitivity to phase transitions, small concentrations of specific defects and impurities $[1,2]$. These changes in crystal structure are easily diagnosed, since they become apparent by luminescent measurements of spectra with characteristic bands at certain wavelengths. These techniques of optical spectroscopy are well developed, and diagnostic tools are available and well-engineered.

Luminescent spectrum shape is sensitive to impurities, stresses, dislocations, nonstoichiometry and inclusions; therefore, systematic study requires qualitative control in sample preparation (see, for example [3]). In addition, many defects can combine together to minimize lattice stresses or electronic mismatches between dopants and lattice points. Luminescent methods enable to monitor the presence of an easily identifiable impurity, for example, a rare-earth metal ion, because there are characteristic emission spectra in this case. It should be noted that it is possible to detect the radiation associated with the defect under study in the spectrum despite the abundance of other defects [4-8].

The mentioned above reasons explain wide use of luminescent techniques not only by physicists [8,9], but also by mineralogists and geologists, as well as by scientists of other specialties (see, for example [10, 11]). Recently, luminescence has been widely put into practice in medical applications, such as optical diagnostic methods of cancer of various types, diseases like caries, dose assessment technique for medical triage [12].

The features of luminescent technique applications for an analysis of various objects were scrupulously discussed (see, for example [13-14]). However, it should be noted that one aspect of luminescent research is poorly covered in publications, namely angular distribution of emitted light. An influence of observation angle on the light flux is more often taken into account in experiments with light emitting objects of limited geometry, such as nanorods, LEDs and various other radiating objects [15-17]. The experimental angular dependence study of the opal nanoscale spheres showed the influence indicatrix (dependence of light intensity on observation angle at certain wavelength) of the observation angle parameter on the measured spectra [18]. But, unfortunately, the reasons for the dependence were not discussed. In order to optimize operation of medical light devices some researchers dealt with the angular distribution of luminescent light from a point Lambert source [19]. It should be noted that they took into account the influence of the CCD cover glass. The results indicated a good agreement of the experimentally measured data with the Monte Carlo simulation of the emitted light angular distribution. Angular distributions of luminescence are also of great importance for X-rays screens in medical imaging detector applications [20]. The simulations and experimental measurements pointed out to a more directional angular distribution in comparison with the predicted Lambert's cosine distribution. The authors took into account absorption and scattering of light in matter in the calculations. When the light is generated inside a transparent extended bulk sample, the angular dependence of light radiation intensity under the surface can also appear due to the refractivity and transmittance on the boundary.

Optical measurements of luminescent radiation have some limitations associated with geometry of experiment (positioning and finite dimensions of registering detector). Light measurements are often carried out in a certain solid angle. Mutual arrangement of the sample being studied and the optics for analysis can define intensity variations of 
luminescent signal. This paper is devoted to the dependence of luminescent intensity on observation angle for transparent polished samples on the example of silica.

\section{EXPERIMENTAL SETUP}

To study the angular characteristics of luminescence, we performed a series of experiments on the irradiation of silica by fast helium and hydrogen ions (both molecular and atomic species). The measurements were carried out at room temperature under vacuum conditions (residual gas pressure not less than $10^{-4} \mathrm{~Pa}$ ) in the experimental setup, which is described in detail here [21]. We used the following bombarding projectiles: $\mathrm{H}_{1}{ }^{+} 210$ and $420 \mathrm{keV}, \mathrm{H}_{2}{ }^{+}$ $420 \mathrm{keV}$ and $\mathrm{He}^{+} 420 \mathrm{keV}$. A beam of ions from the Van de Graaf accelerator passed through the diaphragm system and impinged the target at an angle of $30^{\circ}$ (the angle is measured from the normal to the surface of the target). The beam diameter on the target was $1.5 \mathrm{~mm}$. Luminescent radiation was detected by a spectrometric complex based on the grating monochromator. Light emitted at an observation angle $\beta$ was collected by a light guide with an effective input aperture of $2 \mathrm{~mm}$ (in the plane of incidence). The light guide entrance slit was attached to the movable holder at a distance of $50 \mathrm{~mm}$ from the beam point on the target. It was possible to move the light guide in the plane of beam incidence along the circle with the center at the beam point on the target, thus observation angle could be changed from 0 to $70^{\circ}$. The beam axis, the normal to the target surface and the observation direction were in the same plane. The optical channel (light guide - focusing system - monochromator - photomultiplier) was calibrated by means of incandesce spectrometer lamp. We also measured ion beam current (wire probe diagnostics) simultaneously with the light signal registration. The samples were prepared from $1 \mathrm{~mm}$ thick plane-parallel silica plate with finely polished surface.

\section{EXPERIMENTAL RESULTS}

As it is well-known silica showed bright ionoluminescence in the wavelength region 400-720 nm (visible light), due to intrinsic defects and impurities [22, 23]. In this spectral range, silica has two most common intensive emission peaks (blue with a maximum at $456 \mathrm{~nm}$ and red one at $645 \mathrm{~nm}$ ). In our experiments we obtained the same two-band luminescent spectra with more intensive blue peak in comparison with red one. To study angular luminescent characteristics, we examined the behavior of the blue peak, namely, we studied the indicatrix at a wavelength of $456 \mathrm{~nm}$. Figure 1 shows the generalized angular dependences of luminescence for several types of irradiating ions at low absorption doses (some experimental data were taken from our previous papers: $\mathrm{H}_{1}{ }^{+} 210 \mathrm{keV}$ [21], $\mathrm{He}^{+}$ $420 \mathrm{keV}[24])$. The spectral intensity $I(\beta)$ was normalized to $I\left(0^{\circ}\right)$ value, i.e. $I_{n}(\beta)=I(\beta) / I\left(0^{\circ}\right)$, where $I_{n}(\beta)$ is normalized intensity.

As we mentioned above Lambert's cosine law imposes that the luminous intensity $I(\beta)$ directed at an angle $\beta$, is given as $I(\beta)=I\left(0^{\circ}\right) \cos \beta[25,26]$. Correspondingly, it is reasonable to replot the indicatrix normalized to $\cos \beta$ (see Fig. 2). An additional curve corresponding to a Lambertian angular distribution is also shown for comparison purposes.

As it may be observed from Fig. 1-2: (1) sort of ion has no noticeable effect; (2) the shape of normalized indicatrices differs clearly from the shape of the Lambertian curve. Intensity values corresponding to ionoluminescent indicatrices were found to be higher with respect to values from Lambertian distribution. The difference was found to vary up to approximately $20 \%$ at large observation angles. But Lambert's cosine law one should use only in diffusion solid-ambient surface case. In our experiments samples was polished and experimental distribution can't be explained by that law. Similar dependencies of the indicatrix were observed not only for the maximum of the blue band, but also for the maximum of the red band [27].

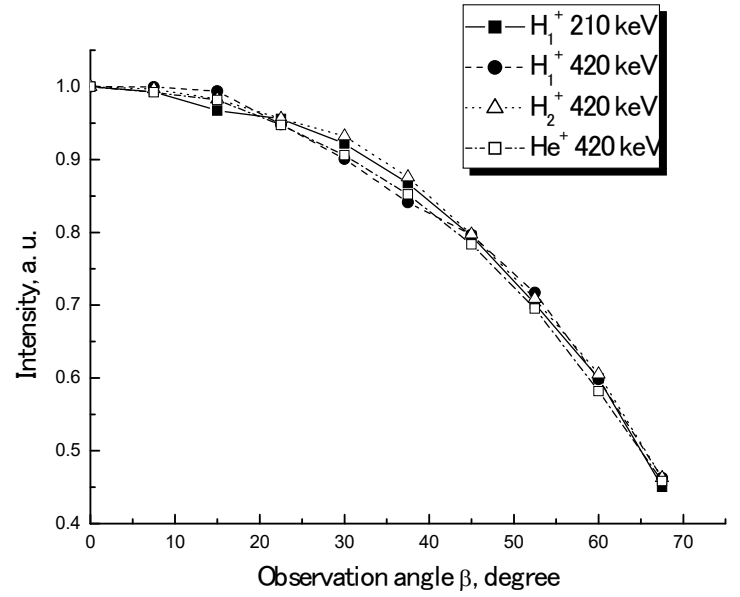

Figure 1. Angular dependences of ionoluminescent intensity for several types of irradiating ions $(\lambda=456 \mathrm{~nm})$

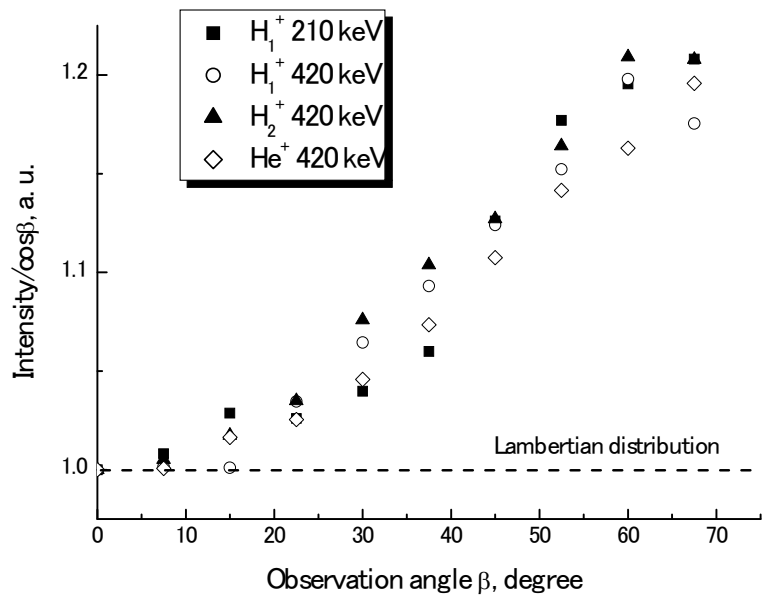

Figure 2. Ionoluminescent angular dependences normalized to $\cos \beta$ 


\section{Angular dependence calculations}

To understand the nature of the angular dependences of luminescence we considered the physical model that includes light refraction and reflection on solid-vacuum boundary. We formulated model's approximation based on analysis of the experimental condition and assumption about spatial distribution and polarization of the luminescent radiation in silica.

As the ions have been accelerated to energies of several hundred $\mathrm{keV}$, the penetration depth reached several microns in silica [28]. The energetic projectiles provide intensive electronic excitation and induce light emission along their trajectories. Despite the fact that there is anisotropy associated with the ion beam, the photon emission is most likely not related to the projectile direction. The diameter of the beam spot on silica target was approximately $1.5 \mathrm{~mm}$, while the distance between light detector (the light guide entrance slit) and silica target was equal $50 \mathrm{~mm}$. So the luminescence is being observed at a distance large compared to the extent of the emitting zone. Taking into account the value of ion penetration depths in silica, we can assume the luminescent source to be point in our proposed model. Schematic representation for our model is presented on Fig. 3.

As far as detector moves in a plane perpendicular to the interface between media (the task is symmetrical with respect to azimuthal angle) the numerical problem is automatically reduced to $2 D$ geometry. As one can see from Fig. 3 $X$-axis coincides with the separating surface and $Y$-axis is perpendicular to it and intersects the point source of luminescence.

The ray of the light emitted from the source at an angle $\alpha$ to the $Y$-axis is passing through the separating surface and refracts due to the difference between refraction indexes $n_{1}$ and $n_{2}$. We neglected absorption of luminescent light within the matter due to low extinction coefficient of silica in our wavelength range. Further the ray is traveling at an angle $\beta$ to the $Y$-axis and enters the detector that moves in $(X, Y)$ plane around the coordinate origin on a constant distance. The current angle position of the detector to the $Y$-axis is denoted by $\beta$.

To obtain relationship between angles of light generation inside a solid $\alpha$ and its further propagation in vacuum $\beta$ we use well-known Snell's law (1)

$$
n_{2} \sin \alpha=n_{1} \sin \beta
$$

that binds the refractive indices with the angles of incidence and refraction.

In order to simulate transmittance distribution one should firstly recall Fresnel's equations [29] that describe the behavior of light pass the separating surface of two media with different refractive indices. The fraction of the intensity $R_{s}$ of light reflected from the boundary for $s$-polarized case is given by

$$
R_{s}=\left|\frac{n_{2} \cos \alpha-n_{1} \sqrt{1-\left(\frac{n_{2}}{n_{1}} \sin \alpha\right)^{2}}}{n_{2} \cos \alpha+n_{1} \sqrt{1-\left(\frac{n_{2}}{n_{1}} \sin \alpha\right)^{2}}}\right|^{2}
$$

and the intensity $R_{p}$ of reflection for $p$-polarized case is

$$
R_{p}=\left|\frac{n_{2} \sqrt{1-\left(\frac{n_{2}}{n_{1}} \sin \alpha\right)^{2}}-n_{1} \cos \alpha}{n_{2} \sqrt{1-\left(\frac{n_{2}}{n_{1}} \sin \alpha\right)^{2}}+n_{1} \cos \alpha}\right|
$$

Following the energy conservation law the corresponding transmittances $T_{s}$ and $T_{p}$ have the forms

$$
T_{s}=1-R_{s}
$$

And

$$
T_{p}=1-R_{p}
$$

When the light includes both $s$ - and $p$-polarizations, for example if it is unpolarized, that means both polarizations are present as half to half. Then the transmittance reads as 


$$
T=1-\frac{1}{2}\left(R_{s}+R_{p}\right)
$$

All the mentioned expressions where included in the numerical code and linked to the expression for angle dependencies (1) that allowed solving the problem of light transmittance at the interface between two media.

On Figure 4 one can see calculated transmittance versus the observation angle $\beta$ dependence for several refractive index values (the data were normalized to the values at $\beta=0^{\circ}$ ).



Figure 3. Schematic representation of light refraction at the interface between two mediums

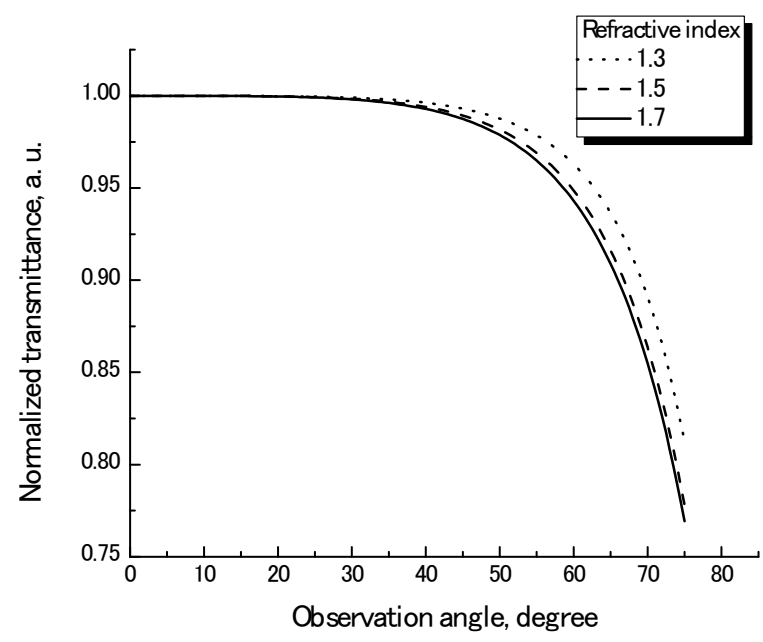

Figure 4. Normalized transmittance versus the detector angle position $\beta$ for different refractive index $n_{2}$ values $\left(n_{1}=1\right)$

Let's consider our $2 D$ geometry experimental case (see Fig. 5 ). $\mathrm{S}$ is point luminescent source. The luminescent light power emitted in some angle range $\Delta \alpha$ from $\alpha_{1}$ to $\alpha_{2}$. It is evident that we registered light emission in the angle $\Delta \beta$, which is corresponding to the angle $\Delta \alpha$ inside the sample. So luminescent intensity of the light collected in small angle $\Delta \beta$ is proportional to value of $\Delta \alpha$. If $\Delta \beta$ is constant (which is most often realized in experiments), $\Delta \alpha$ will depend on $\beta$ due to refractive law at the sample surface.

Snell's law defines the relationship between angles:

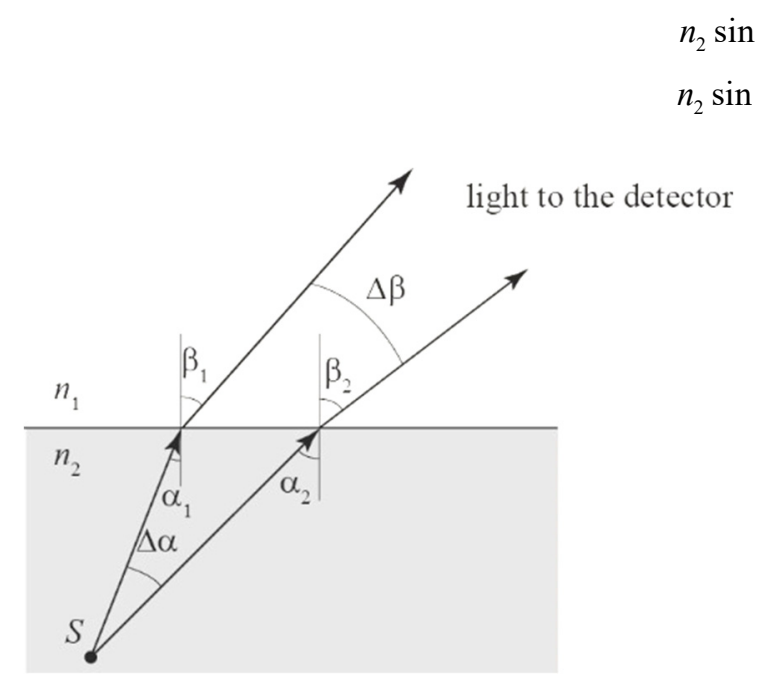

Figure 5. Luminescent light refraction at the interface between two mediums

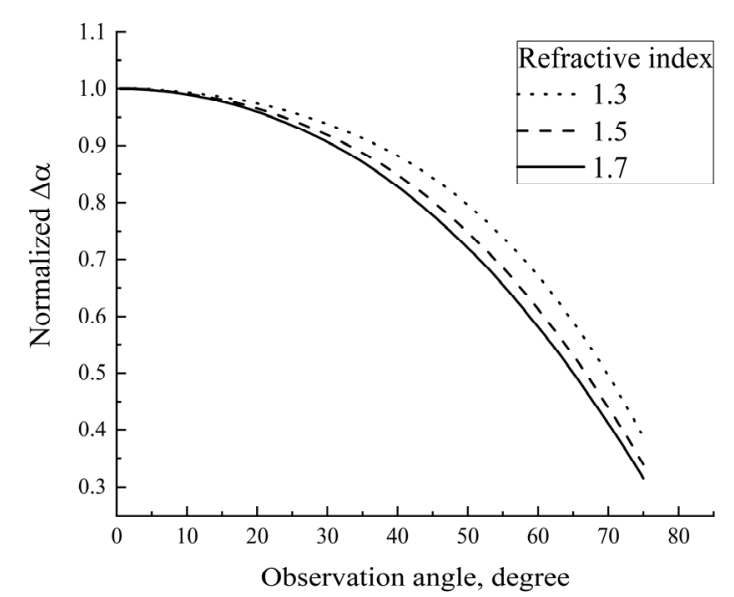

Figure 6. The normalized relation between $\Delta \alpha$ and the detector angle position for different refractive indices $n_{2}\left(n_{1}=1\right)$

As we mentioned above, for our experimental geometry the light guide entrance slit had dimension of $2 \mathrm{~mm}$ and moved along a circle with a diameter of $50 \mathrm{~mm}$. In our case constant angle $\Delta \beta$ during the indicatrix measurements has value $\approx 2^{\circ}$ (so we can consider this angle as small). It is possible to relate the detector angle position $\beta$ and angles $\beta_{1}, \beta_{2}$ :

$$
\begin{aligned}
& \beta_{2}=\beta+\frac{\Delta \beta}{2} \\
& \beta_{1}=\beta-\frac{\Delta \beta}{2}
\end{aligned}
$$


Using expressions (7-10) it is possible to calculate $\Delta \alpha=\alpha_{2}-\alpha_{1}$ depending on the detector angle position $\beta$. The dependence $\Delta \alpha=f(\beta)$ was calculated for three refractive indices (see Fig. 6).

As we pointed out earlier luminescent intensity of the light collected by the detector is proportional to value of $\Delta \beta$, this nonlinear dependence $\Delta \alpha=f(\beta)$ predicts that registered luminescent intensity is changed at different observation directions. For example for $n_{2}=1.5$ normalized $\Delta \alpha$ changes from $1\left(\right.$ at $\beta=0^{\circ}$ ) to 0.35 (at $\beta=75^{\circ}$ ). It means that different detector positioning relative to the luminescent source leads to the intensity variations.

\section{Validation of calculation model and discussion}

Taking into account our previous calculations, indicatrix for the light leaving solid will be affected by the dependencies of the transmittance and reflectance. We calculated the normalized transmittance $T$ and the normalized dependence $\Delta \alpha$ versus the detector angle position $\beta$ for the silica case. The refractive index of silica at $456 \mathrm{~nm}$ is approximately 1.46 [30]. The result is analogical to one shown on Fig. 4 and Fig.6. Assume that light from point source is isotropic within silica and unpolarized light ( $s$ - and $p$-polarizations are present as half to half), then the indicatrix is constant for any angle $\alpha\left(I(\alpha)=I_{0}\right)$. We calculated normaled functional dependence of the luminescent light collected by our detector on observation angle by multiplying the indicatrix within silica by the mentioned above relations $I(\beta)=I_{0} \cdot T(\beta) \cdot \Delta \alpha(\beta)$ (see solid curve on Fig. 7). We also showed on Fig. 7 the average experimental indicatrix based on our data for different projectiles under study and Lambertian (to perform comparative analysis we normalized the data to $I\left(0^{\circ}\right)$ values).

The results of calculated angular distribution are in good agreement with the experimental average indicatrix curve. This agreement confirms applicability of our model and initial assumption, that the light is initially unpolarized and emitted isotropically within silica.

We performed the calculations for our specific experiment. The reception path of the monochromator always limits the angular size of the region from which light is collected. In general, obtained results can be adapted for other cases. For that one has to vary $\Delta \beta$ and solid refractive index in equations. Moreover, two aspects must be taken into account. If there are other factors affecting the angular distribution (for example the presence of optical filters or etc.), then this can be taken into account in the indicatrix by multiplying by the corresponding dependence. Secondly, when you deal with substances with a strong dispersion in the wavelength range under study, not only the intensity but also the shape of the luminescence spectrum can change.

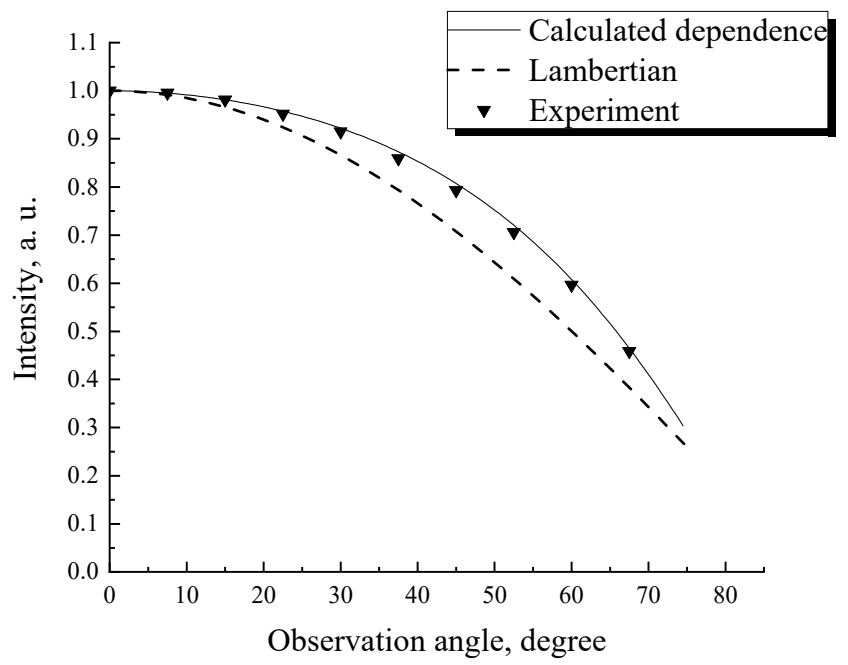

Figure 7. Normalized indicatrices of silica luminescent light: measured average angular dependence of light emission (squares), calculated angular distribution (solid curve), Lambert's cosine law (dashed curve).

\section{CONCLUSION}

The influence of the observation angle on the measured intensity of the luminescent radiation induced by ions from silica was shown. The functional angular dependence is significantly different from the well-known Lambert's law. The previously obtained experimental angular dependences of the silica ionoluminescence for several types and ion energies were the basis for the calculations performed. A good agreement between the experimental data and the calculated angular distribution was obtained.

The results obtained make it possible to draw the following conclusions:

a) Luminescent light generated by fast ions within silica is unpolarized and isotropic.

b) Geometry of the experiment is very important. Considering the light collected by the measuring system in a certain solid angle, one has to take into account that mutual arrangement of the sample and detector can distort angular distribution. 
c) The refraction at the interface between the sample and vacuum (or air) strongly influences the luminescent light indicatrix.

The results are applicable for any glossy transparent materials.

\section{ORCID IDs}

(1DSergiy Kononenko, https://orcid.org/0000-0001-6060-2589; (DIllia Mysiura, https://orcid.org/0000-0002-1401-6412;

(DV) Vitaliy Zhurenko, https://orcid.org/0000-0002-4738-094X; (DOganes Kalantaryan, https://orcid.org/0000-0002-5625-6908

\section{REFERENCES}

[1] P.D. Townsend, B. Yang, and Y. Wang, Revista Mexicana De Fisica S, 54(2), 29-38 (2008), http://www.scielo.org.mx/pdf/rmf/v54s2/v54s2a5.pdf.

[2] O. Pen a-Rodri'guez, D. Jime'nez-Rey, J. Manzano-Santamarı'a, J. Olivares, A. Muñoz, A. Rivera, and F. Agulló-López, Appl. Phys. Express 5(1), 011101 (2012), https://doi.org/10.1143/APEX.5.011101.

[3] P.D. Townsend, M. Khanlary, and D.E. Hole, Surf. \& Coat. Tech. 201, 8160 (2007), https://doi.org/10.1016/j.surfcoat.2006.01.075.

[4] P.D. Townsend, and Y. Wang, Energy Proc. 41, 64 (2013), https://doi.org/10.1016/j.egypro.2013.09.008.

[5] M.L. Crespillo, J.T. Graham, Y. Zhang, and W.J. Weber, J. Lumin. 172, 208 (2016), https://doi.org/10.1016/j.jlumin.2015.12.016.

[6] D. Jimenez-Rey, O. Peña-Rodríguez, J. Manzano-Santamaría, J.Olivares, A.Muñoz-Martin, A.Rivera, and F.Agulló-López, Nucl. Instr. and Meth. Phys. Res. B, 286, 282 (2012), https://doi.org/10.1016/j.nimb.2011.12.025.

[7] R. Skiba, I. Mysiura, O. Kalantaryan, V. Zhurenko, and S. Kononenko, East Eur. J. Phys. 4, 93 (2018), https://doi.org/10.26565/2312-4334-2018-4-11.

[8] P.D. Townsend, Nucl. Instr. and Meth. Phys. Res. B, 286, 35 (2012), https://doi.org/10.1016/j.nimb.2011.10.070.

[9] A. Finch, J. Garcia-Guinea, D. Hole, P.D. Townsend, and J.M. Hanchar, J. Phys. D: Appl. Phys. 37, 2795 (2004), https://doi.org/10.1088/0022-3727/37/20/004.

[10] H. Calvo del Castillo, N. Deprez, T. Dupuis, F. Mathis, A. Deneckere, P. Vandenabeele, T. Calderón, and D. Strivay, Anal. Bioanal. Chem. 394, 1043 (2009), https://doi.org/10.1007/s00216-009-2679-y.

[11] G. Valotto, A. Quaranta, E. Cattaruzza, F. Gonella, and G. Rampazzo, Spectrochem. Acta Part A: Mol. Biomol. Spectrosc. 95, 533 (2012), https://doi.org/10.1016/j.saa.2012.04.045.

[12] R. De Witt, D.M.Klein, E.G. Yukihara, S.L. Simon, and S.W.S. McKeever, Health Phys. 98(2), 432 (2010), https://doi.org/10.1097/01.HP.0000347997.57654.17.

[13] P.D. Townsend, and M.L. Crespillo, Phys. Proc. 66, 345 (2015), https://doi.org/10.1016/j.phpro.2015.05.043.

[14] Y. Wang, and P.D. Townsend, J. Lumin. 142, 202 (2013), https://doi.org/10.1016/j.jlumin.2013.03.052.

[15] N.C. Greenham, R.H. Friend, D.D.C. and Bradley, Adv. Mater. 6(6), 491 (1994), https://doi.org/10.1002/adma.19940060612.

[16] F.A. Ponce, D.P. Bour, W. Götz, and P.J. Wright, Appl. Phys. Lett. 68, 57 (1996), https://doi.org/10.1063/1.116756.

[17] D.C. Marra, E.S. Aydil, S.-J. Joo, E. Yoon, and V.I. Srdanov, Appl. Phys. Lett. 77(21), 3346 (2000), https://doi.org/10.1063/1.1326837.

[18] A. N. Gruzintsev, Inorg. Mat. 51(11), 1127 (2015) https://doi.org/10.1134/S0020168515110023.

[19] G.M. Haak, N.L. Christensen, and B.E. Hammer, Nucl. Instr. and Meth. Phys. Res. A, 390, 191 (1997), https://doi.org/10.1016/S0168-9002(97)00355-0.

[20] I. Kandarakis, D. Cavouras, D. Nikolopoulos, A. Episkopakis, N. Kalivas, P. Liaparinos, I. Valais, G. Kagadis, K. Kourkoutas, I. Sianoudis, N. Dimitropoulos, C. Nomicos, and G. Panayiotakisc, App. Rad. Isot. 64, 508 (2006), https://doi.org/10.1016/j.apradiso.2005.11.016.

[21] S. Kononenko, O. Kalantaryan, V. Muratov, and V. Zhurenko, Radiation Measurements, 42, 751 (2007), https://doi.org/10.1016/j.radmeas.2007.02.061.

[22] P.J. Chandler, F. Jaque, and P.D. Townsend, Rad. Eff. 42(1-2), 45 (1979), https://doi.org/10.1080/10420157908201735.

[23] R. Salh, in: Crystalline Silicon - Properties and Uses (InTech, 2011), pp. 135-172, http://dx.doi.org/10.5772/22607.

[24] V. Zhurenko, O. Kalantaryan, S. Kononenko, I. Mysiura, and E. Barannik, Nucl. Instr. Meth. Phys. Res. B, 407, 5 (2017), https://doi.org/10.1016/j.nimb.2017.05.038.

[25] A.N. Matveev, Optics (Mir, Moscow, 2000).

[26] E.F. Zalewski, in: Handbook of Optics, edited by M. Bass (Mc Graw-Hill, New York, 1995).

[27] O. Kalantaryan, S. Kononenko, and V. Zhurenko, Func. Mat. 20(4), 462 (2013), http://dx.doi.org/10.15407/fm20.04.462.

[28] J.F. Ziegler, M.D. Ziegler, and J.P. Biersack, Nucl. Instr. Meth. Phys. Res. B, 268(11-12), 1818 (2010), https://doi.org/10.1016/j.nimb.2010.02.091.

[29] M. Born, and E. Wolf, Principles of Optics (Cambridge University Press, Cambridge, 2002).

[30] I.H. Malitson, J. Opt. Soc. Am. 55(10), 1205 (1965), https://doi.org/10.1364/JOSA.55.001205.

\section{КУТОВА ЗАЛЕЖНІСТЬ ЙОНОЛЮМІНЕСЦЕНЦІЇ ДЛЯ КВАРЦЕВОГО СКЛА \\ С. Кононенко, І. Мисюра, В. Журенко, О. Шишкін, О. Калантар'ян \\ Харківський Начіональний університет ім. В.Н. Каразіна \\ 61022, Україна, м. Харків, пл. Свободи, 4}

У статті розглядається кутова залежність йонолюмінесценції для прозорих полірованих зразків кварцового скла. Ми виміряли спектри йонолюмінесценцію кварцового скла в діапазоні довжин хвиль 400-700 нм для різних бомбардуючих йонів $\left(\mathrm{H}_{1}^{+}, \mathrm{H}_{2}+, \mathrm{He}^{+} 210\right.$ та 420 кэВ) та зареєстрували два відомих найпоширеніших піки інтенсивного випромінювання (синій з максимумом біля 456 нм та червоний — 645 нм). Для вивчення кутової залежності люмінесценції було досліджено поведінку максимуму синього піку як функцію кута спостереження в діапазоні $0-70^{\circ}$, а саме було знайдено індикатрису на довжині хвилі 456 нм. Встановлено, що інтенсивність, яка відповідає йонолюмінесцентним індикатрисам, вища значень, 
характерних для кутового розподілу Ламберта, сягаючи значень перевищення приблизно 20 \% для великих кутів спостереження. Ми також розрахували кутовий розподіл світла над поверхнею зразка з урахуванням заломлення та відбиття на поверхні твердого тіла. Отримані результати добре узгоджуються 3 експериментальними даними щодо йонолюмінесценції кварцового скла $\left(\mathrm{H}_{1}^{+}, \mathrm{H}_{2}{ }^{+}, \mathrm{He}^{+} 210\right.$ та 420 кеВ), а саме середньою індикатрисою. Останнє вказує на правильність модельного припущення (люмінесцентне світло, яке генерується швидкими іонами в кварцовому склі, $\epsilon$ неполяризованим та ізотропним). Було продемонстровано, що геометрія експерименту дуже важлива, тобто, аналізуючи світло, яке збирає вимірювальна система під певним тілесним кутом, слід враховувати, що взаємне розташування зразка та детектора може вплинути на кутовий розподіл. Заломлення на межі розділу зразка та вакууму (або повітря) сильно впливає на кутовий розподіл люмінесцентного світла.

КЛЮЧОВІ СЛОВА: $\mathrm{SiO}_{2}$, спектроскопія, заломлення, відбиття, йони, радіолюмінесценція, спектр, індикатриса

\section{УГЛОВАЯ ЗАВИСИМОСТЬ ИОНОЛЮМИНЕСЦЕНЦИИ ДЛЯ КВАРЦЕВОГО СТЕКЛА \\ С. Кононенко, И. Мисюра, В. Журенко, А. Шишкин, О. Калатарьян \\ Харьковский национальный университет им. В. Н. Каразина}

61022, Украина, г. Харьков, пл. Свободы, 4

В статье рассматривается угловая зависимость ионолюминесценции прозрачных полированных образцов кварцевого стекла. Мы измерили спектры ионолюминесценции кварцевого стекла в диапазоне длин волн 400-700 нм для различных бомбардирующих ионов $\left(\mathrm{H}_{1}^{+}, \mathrm{H}_{2}{ }^{+}, \mathrm{He}^{+} 210\right.$ и 420 кэВ) и зарегистрировали два известных распространенных пика интенсивного излучения (синий с максимумом около 456 нм и красный - 645 нм). Для изучения угловой зависимости люминесценции было исследовано поведение максимума синего пика как функцию угла наблюдения в диапазоне $0-70^{\circ}$, a, именно, была найдена индикатриса на длине волны 456 нм. Установлено, что интенсивность, которая соответствует ионолюминесцентным индикатрисам, выше значений, характерных для углового распределения Ламберта, достигая превышения примерно $20 \%$ для больших углов наблюдения. Мы рассчитали угловое распределение света над поверхностью образца с учетом преломления и отражения на поверхности твердого тела. Полученные результаты хорошо согласуются с экспериментальными данными по ионолюминесценции кварцевого стекла $\left(\mathrm{H}_{1}^{+}, \mathrm{H}_{2}^{+}, \mathrm{He}^{+} 210\right.$ и 420 кэВ), а, именно, средней индикатрисой. Последнее указывает на правильность модельного предположения (люминесцентный свет, генерируемый быстрыми ионами в кварцевом стекле, является неполяризованным и изотропным). Было продемонстрировано, что геометрия эксперимента очень важна, то есть, анализируя свет, который собирает измерительная система под определенным телесным углом, следует учитывать, что взаимное расположение образца и детектора может повлиять на угловое распределение. Преломление на границе между образцом и вакуумом (или воздухом) сильно влияет на угловое распределение люминесцентного света.

КЛЮЧЕВЫЕ СЛОВА: $\mathrm{SiO}_{2}$, спектроскопия, преломление, отражение, ионы, радиолюминесценция, спектр, индикатрисса 